\title{
Evaluation of Lyophilized Myrtle Pulp Powder Stability During Storage
}

\author{
Regilane Marques Feitosa \\ Federal institute of education, Science, and technology of Alagoas, Campus Piranhas, \\ Piranhas, AL, Brazil, E-mail: regilanemarques@gmail.com
}

Rossana Maria Feitosa de Figueirêdo, Alexandre José de Melo Queiroz, Renato Costa da Silva, Emanuel Neto Alves de Oliveira

Federal University of Campina Grande (UFCG), agricultural engineering department, 58429-140, Brazil

\author{
Inacia dos Santos Moreira (Corresponding author) \\ Federal University of Campina Grande \\ Campina Grande, Paraíba, Brazil
}

Tel: 55-083 2101-1055Ｅ-mail: inaciamoreira@ymail.com

Received: Sep. 16, 2019 Accepted: Oct. 24, $2019 \quad$ Published: Oct. 27, 2019

doi:10.5296/jas.v8i1.15447

URL: https://doi.org/10.5296/jas.v8i1.15447

\begin{abstract}
Myrtle is a fruit with great industrial potential, due to its nutritional characteristics and presence of phenolic compounds, especially anthocyanins. Nonetheless, the high perishability and short post-harvest life of this fruit limit its diffusion in the internal market and use in the food processing industry. Lyophilization of fruit pulps represents an alternative to increasing preservation time, resulting in a powder with higher stability and longer shelf life. In this context, this study was aimed to evaluate the stability of myrtle pulp powder during storage in laminated packages and under controlled conditions of temperature (between 30 and $40{ }^{\circ} \mathrm{C}$ ), and evaluate the kinetics of degradation of anthocyanins and flavonoids. As storage time increased at both temperatures, moisture content and water activity increased; and caused reductions of anthocyanins, flavonoids and lightness. In the evaluation of the kinetics of degradation of anthocyanins and flavonoids, the zero-order was the best model to represent the behavior and with higher stability at a temperature of $20^{\circ} \mathrm{C}$.
\end{abstract}


Keywords: quality, storage, anthocyanins, degradation kinetics

\section{Introduction}

Myrtle is a fruit native to the Northeast region, rich in anthocyanins, little exploited and disseminated, but its production in the form of powder is an alternative that may be widely accepted, since it stands out for the taste and attractive color, leading to the increase of the interest in cultivation and consumption because it creates curiosity in consumers that seek innovative products. Currently, there is an increasing market for powder products and this trend is observed every day, due to the practicality and advantages offered by this type of product.

Powder products have many benefits and economic potential over the liquid ones, promote reduced weight and packages, higher stability, longer shelf life and easy storage, handling and transport (Ferrari et al., 2012), besides inhibiting the growth of microorganisms and enzymatic activity (Jangam et al., 2014; Mishra et al., 2014).

Stability of powders can be maintained for a certain period by controlling the chemical interactions and activity of enzymes and microorganisms (Moura, 2010). Hence, the choice on the adequate storage conditions and packaging materials is of great importance to maintain quality and extend shelf life (Tehrany and Sonneveld, 2010). Aluminum-plastic laminates have a preservation effect on the attribute of quality of food powders, but it is worth investigating the effects of external environmental factors, such as temperature and relative humidity, which also affect the powders' shelf life (Yu et al., 2015). During storage and distribution, foods are exposed to various environmental conditions such as temperature and relative humidity, which may favor the numerous alterations and reactions that lead to degradation, causing non-acceptance of the product.

Food shelf life can be influenced by various factors, such as processing conditions, type of package, initial microbial load and storage time and temperature. Among these factors, temperature is usually the most important determinant, because it can accelerate the oxidation of certain nutrients and, through this, alter nutritional and sensory properties of the products (Oliveira et al., 2013a). For foods with considerably long shelf life, accelerated shelf-life tests (ASLT) are normally employed. In these tests, products are subjected to relatively severe, well-defined and controlled storage conditions, accelerating the transformation rates (Moura et al., 2007).

Based on the above, this study is aimed to evaluate the stability of the myrtle pulp powder during storage in laminated packages and under controlled conditions of temperature (between 30 and $40{ }^{\circ} \mathrm{C}$ ) and evaluate the kinetics of degradation of anthocyanins and flavonoids.

\section{Material and Methods}

Myrtle (Eugenia gracillima Kiaersk) fruits, the raw material used, came from the Serra dos Paus Dóias, Araripe Plateau, municipality of Exu, PE, Brazil. The myrtle fruits were manually selected, by eliminating those with physical damage, rotting aspect or at another 
maturation stage. Then, they were subjected to washing in running water and sanitation in 50 -ppm sodium hypochlorite solution for 15 minutes, and rinsed in running water. After natural drainage of water, fruits were pulped in a mechanical pulping machine and the whole pulp was packed in low-density polyethylene (LDPE) bags and stored in the freezer at $-22{ }^{\circ} \mathrm{C}$, until its use. The elaborated formulation was composed of the myrtle pulp and $20 \%$ of maltodextrin (MOR-REX®), donated by the Corn Products Brasil with dextrose equivalent (DE) of 10, being homogenized in a blender and then frozen in a domestic freezer for 72 hours. The cubes were lyophilized in a lyophilizer (Terroni - Model LS 3000) and ground by the mortar and pestle, to obtain the myrtle powder.

\subsection{Accelerated Storage}

Powder samples were placed into the flexible laminated packages composed of one layer of crystal PET $(12 \mu \mathrm{m})$, one layer of metal PET $(12 \mu \mathrm{m})$, and one layer of crystal LDPE $(50 \mu \mathrm{m})$, resulting in a total thickness of approximately $74 \mu \mathrm{m}$. The packages were $10 \mathrm{~cm}$ long and 9 $\mathrm{cm}$ wide, each one containing $10 \mathrm{~g}$ of the powder sample, closed with a mechanical sealing machine. After that, three packages containing the samples were placed in airtight glass containers with saturated solutions of potassium chloride $(\mathrm{KCl})$, promoting an environment with controlled relative humidity of $84.34 \%$ at temperature of $30{ }^{\circ} \mathrm{C}$ and $82.32 \%$ at temperature of $40{ }^{\circ} \mathrm{C}$. These containers with the powder samples were placed in BOD chambers at these temperatures and subjected to accelerated storage for 60 days.

Stability of the powder samples was monitored at time zero and every 15 days, through the determination of quality parameters: moisture content, $\mathrm{pH}$, total titratable acidity (\% citric acid), using the methodologies of IAL (2008); anthocyanins and flavonoids (Francis, 1982); water activity at $25^{\circ} \mathrm{C}$, quantified by direct reading in Aqualab (Decagon); and color, determined in a portable spectrophotometer (Hunter Lab - Model Mini Scan XE Plus 4500 L), obtaining the parameters lightness $\left(\mathrm{L}^{*}\right)$ and chromaticity $\left(+\mathrm{a}^{*}\right.$ red; $-\mathrm{a}^{*}$ green; $+\mathrm{b}^{*}$ yellow; and $-b^{*}$ blue). After obtaining the values of the coordinates $\mathrm{L}^{*}, \mathrm{a}^{*}$ and $\mathrm{b}^{*}$, we calculated the total color difference $\left(\Delta \mathrm{E}^{*}\right)$ (Equation 1); chroma (Equation 2); and hue angle (Equation 3 ).

$$
\Delta \mathrm{E}^{*}=\left[\left(\Delta L^{*}\right)^{2}+\left(\Delta a^{*}\right)^{2}+\left(\Delta b^{*}\right)^{2}\right]^{1 / 2}
$$

Where:

$\Delta E^{*}$ - total color difference;

$\Delta L^{*}$ - difference between powder lightness at time zero and at every time;

$\Delta a^{*}$ - difference between powder redness at time zero and at every time;

$\Delta b^{*}$ - difference between powder yellowness at time zero and at every time.

$$
C^{*}=\left[\left(a^{*}\right)^{2}+\left(b^{*}\right)^{2}\right]^{1 / 2}
$$




$$
H=\operatorname{arctg}\left(\frac{b^{*}}{a^{*}}\right)
$$

The statistical analysis of the experimental data was performed using the computer program ASSISTAT Beta version 7.5 (Silva and Azevedo, 2009). The experimental design was completely randomized, in $2 \times 5$ factorial scheme, with 2 temperatures $\left(30\right.$ and $40{ }^{\circ} \mathrm{C}$ ) and 5 storage times $(0,15,30,45$ and 60 days), with 3 replicates. Means were compared by Tukey test at 0.05 probability level.

\subsection{Degradation Kinetics}

Myrtle powder samples were subjected to the study of the kinetics of degradation of anthocyanins and flavonoids, daily evaluated for 15 days, at temperatures of 20,30 and $40{ }^{\circ} \mathrm{C}$. The samples were placed in airtight glass containers, without packages (in containers that allowed direct contact between samples and the desired environment) with saturated solutions of potassium chloride $(\mathrm{KCl})$. Zero-, first- and second-order kinetic models (Table 1) were fitted to the experimental data, determining the reaction speed constants $(k)$. The best model was selected based on the coefficient of determination $\left(\mathrm{R}^{2}\right)$. Half-life times $\left(\Theta_{(1 / 2)}\right)($ Table 1$)$ were calculated using the $\mathrm{k}$ values of the kinetic model that fitted best to the experimental data of the kinetics of degradation of anthocyanins, flavonoids and of the color.

Table 1. Zero-, first- and second-order kinetic models and half-life times

Order of reaction

Zero

First

Second

First
Model

$$
A=A_{0}-k \theta
$$$$
\theta_{1 / 2}=\frac{1}{k}\left(A_{0}-\frac{A_{0}}{2}\right)
$$

Half-life time $\left(\Theta_{(1 / 2)}\right)$

$$
\ln \frac{A}{A_{0}}=-k \theta
$$$$
\theta_{(1 / 2)}=\frac{0.693}{k}
$$

$$
\frac{1}{A}=\left(\frac{1}{A_{0}}\right)+k t
$$

$$
\theta_{1 / 2}=\frac{1}{k}\left(A_{0}\right)
$$

Where: $\mathrm{A}$ - concentration of the evaluated parameter after a time $\theta ; \mathrm{A}_{0}$ - initial concentration of the evaluated parameter; $k$-reaction speed constant; $\theta$ - time.

To evaluate the effect of temperature on the speed constant $(k)$ of the degradation reaction of 


\section{Macrothink}

Journal of Agricultural Studies

ISSN 2166-0379 2020, Vol. 8, No. 1

anthocyanins, flavonoids and color, the Arrhenius-type equation (Equation 4) was used. Again, the k value used came from the model that fitted best to the experimental data of the kinetics of degradation of anthocyanins, flavonoids and color.

$$
\ln k=\ln A-\frac{E_{a}}{R T}
$$

Where:

$k-$ reaction speed constant;

A - pre-exponential factor;

$\mathrm{E}_{\mathrm{a}}$ - activation energy $\left(\mathrm{kJ} \mathrm{mol}^{-1}\right)$;

$\mathrm{R}$ - universal gas constant, $0.008314 \mathrm{~kJ} \mathrm{~mol}^{-1} \mathrm{~K}^{-1}$;

$\mathrm{T}$ - absolute temperature, $\mathrm{K}$

The factor Q10 indicates the increase or decrease in the rate of a reaction, when the product is stored at a temperature $10{ }^{\circ} \mathrm{C}$ higher, and was determined by Equation 5 .

$$
Q_{10}=\frac{k_{(T+10)}}{k_{T}}
$$

Where:

$k$ - reaction speed constant;

$\mathrm{T}$ - absolute temperature, $\mathrm{K}$.

\section{Results and Discussion}

\subsection{Accelerated Storage}

Table 2 shows the mean values of moisture content, water activity and $\mathrm{pH}$ obtained during the storage of myrtle powder.

Table 2. Mean values of moisture content, water activity and $\mathrm{pH}$ of myrtle powder in laminated package during storage at different temperatures

\begin{tabular}{ccccccc}
\hline \multirow{2}{*}{$\begin{array}{c}\text { Time } \\
\text { (days) }\end{array}$} & \multicolumn{2}{c}{ Moisture content $(\boldsymbol{\%})$} & \multicolumn{2}{c}{ Water activity } & \multicolumn{2}{c}{$\mathbf{p H}$} \\
\cline { 2 - 7 } $\mathbf{3 0}^{\circ} \mathbf{C}$ & $\mathbf{4 0}{ }^{\circ} \mathbf{C}$ & $\mathbf{3 0}{ }^{\circ} \mathbf{C}$ & $\mathbf{4 0}^{\circ} \mathbf{C}$ & $\mathbf{3 0}^{\circ} \mathbf{C}$ & $\mathbf{4 0}^{\circ} \mathbf{C}$ \\
\hline 0 & $7.60 \mathrm{bA}$ & $7.52 \mathrm{cA}$ & $0.189 \mathrm{cA}$ & $0.189 \mathrm{dA}$ & $3.73 \mathrm{aA}$ & $3.73 \mathrm{aA}$ \\
15 & $8.54 \mathrm{abA}$ & $9.07 \mathrm{bcA}$ & $0.245 \mathrm{bB}$ & $0.263 \mathrm{cA}$ & $3.58 \mathrm{aA}$ & $3.51 \mathrm{abA}$ \\
30 & $8.81 \mathrm{abA}$ & $9.69 \mathrm{bA}$ & $0.264 \mathrm{abB}$ & $0.295 \mathrm{bA}$ & $3.51 \mathrm{aA}$ & $3.47 \mathrm{abA}$ \\
45 & $9.14 \mathrm{abA}$ & $10.19 \mathrm{bA}$ & $0.263 \mathrm{abB}$ & $0.301 \mathrm{abA}$ & $3.42 \mathrm{aA}$ & $3.39 \mathrm{abA}$ \\
60 & $9.95 \mathrm{aB}$ & $12.01 \mathrm{aA}$ & $0.283 \mathrm{aB}$ & $0.323 \mathrm{aA}$ & $3.41 \mathrm{aA}$ & $3.27 \mathrm{bA}$ \\
\hline
\end{tabular}

Means followed by the same lowercase letter in the columns and upper case letters in the rows do not differ statistically by the Tukey test at $5 \%$ probability. 
Moisture content found in the samples stored at temperatures between 30 and $40{ }^{\circ} \mathrm{C}$ tended to increase during storage (Table 2). Similar behavior was observed by Oliveira et al. (2015), who stored mandacaru powder for 50 days at $25^{\circ} \mathrm{C}$, with relative humidity of $57.7 \%$, dried in a spray dryer, with $10 \%$ of maltodextrin $(\mathrm{DE}=10$ and 14$)$, and claimed that laminated packages did not prevent water absorption, and by Loureiro et al. (2013), who obtained burrito powder by oven drying at 50,60 and $70{ }^{\circ} \mathrm{C}$, stored in laminated package (one $12-\mu \mathrm{m}$-thick layer of metalized PET and one $78-\mu \mathrm{m}$-thick layer of LDPE), and found that the moisture content remained statistically unchanged until 75 days of storage and statistically increased from 75 to 90 days.

The sample stored at $30^{\circ} \mathrm{C}$ exhibited a more efficient behavior against the absorption of water, not differing statistically from the time zero to 45 days, and there was no statistical difference from the time of 15 to 60 days. Hence, laminated package, at temperature of $30{ }^{\circ} \mathrm{C}$, showed characteristics for a good storage of the powder, which in addition remained with moisture content lower than $10 \%$. Moisture content lower than $10 \%$ is sufficient to ensure the powder is microbiologically safe (Tze et al., 2012).

Between the temperatures $\left(30\right.$ and $40{ }^{\circ} \mathrm{C}$ ), the moisture content did not differ from time zero to 45 days of storage, except at the time of 60 days, when the sample stored at temperature of $40{ }^{\circ} \mathrm{C}$ showed higher moisture content compared with that at $30{ }^{\circ} \mathrm{C}$. Galdino et al. (2016) analyzed cactus-pear powder stability, at temperatures of 25 and $40{ }^{\circ} \mathrm{C}$, and reported that moisture content significantly increased along the storage time for the studied temperatures, and such increment was more evident at $40{ }^{\circ} \mathrm{C}$, from the period of 10 days on, indicating that temperature significantly influenced moisture absorption. Hygroscopic characteristics of foods depend mainly on their chemical composition and storage conditions (temperature and relative air humidity) (Arlindo et al., 2007).

Water activity $\left(\mathrm{a}_{\mathrm{w}}\right)$ of the powder at temperature of $30^{\circ} \mathrm{C}$ increased slowly during storage. Stability was observed from 30 to 60 days. Increment in water activity is expected in the storage of packages that are not completely impermeable (Oliveira et al., 2015). Costa et al. (2013) observed that water activity of passion fruit powder varied from 0.42 to 0.47 along storage, justifying that such increase was due to the increment in the moisture content of the passion fruit powder and claiming that the storage conditions were safe, since pathogenic bacteria cannot grow at low values of water activity.

Water activity of the powder stored at temperature of $40{ }^{\circ} \mathrm{C}$ gradually increased, and such increment was more accentuated than that at $30^{\circ} \mathrm{C}$. That means the temperature of $30^{\circ} \mathrm{C}$ was more effective to prevent the increase of water activity. Despite exhibiting increment in aw, it can be said that, at both temperatures, the powder was free from the action of microorganisms and other reactions, because its aw was lower than 0.6 . Water activity below 0.6 is considered stable against the action of microorganisms, hydrolytic reaction, lipid oxidation, autoxidation and enzymatic activity (Caliskan and Dirim, 2013). Wong and Lim (2016) evaluated papaya powder dried in spray dryer and stored $\left(38{ }^{\circ} \mathrm{C}, 90 \%\right.$ relative air humidity) for 7 weeks in laminated packages (polyethylene and aluminum) and polyethylene terephthalate (PET), and found that the final water activity did not exceed 0.6 in the tested packages, claiming that the 
powder was stable during the shelf life. Between the temperatures, the lowest aw values occurred at $30^{\circ} \mathrm{C}$.

The $\mathrm{pH}$ (Table 2) and total titratable acidity (Table 3 ) of the myrtle powder stored for 60 days at temperatures of 30 and $40{ }^{\circ} \mathrm{C}$ did not show significant difference, indicating that it did not undergo alterations related to storage time and effect of temperature, except for the $\mathrm{pH}$ of the powder stored at $40{ }^{\circ} \mathrm{C}$, which decreased only at 60 days in comparison to the initial time. Han et al. (2016) also observed no alterations in the mushroom powder stored at temperatures of $-20,4,25$ and $35^{\circ} \mathrm{C}$, for 9 months, claiming that for a food to have prolonged shelf life, it is necessary to control acidity, $\mathrm{pH}$ and water activity level. Galdino et al. (2016) stored cactus pear powders at temperatures of 25 and $40{ }^{\circ} \mathrm{C}$, and reported that the mean values of total titratable acidity of samples stored at both temperatures underwent small oscillations along the storage time. However, in general, the authors claimed that the samples did not undergo significant alterations, indicating that there was no evidence of microbiological contamination.

Along the storage, the samples showed $\mathrm{pH}$ below 4.5, a range considered as restrictive to the development of microorganisms, and the powders were considered acidic. The stability of total acidity is a positive factor because, for Cecchi (2003), variation in this constituent may be associated with the oxidation of the organic acids present, which affect the taste, smell, color, stability and maintenance of quality of the foods.

Table 3 shows the mean values of total titratable acidity, anthocyanins and flavonoids obtained during the storage of myrtle powder.

Table 3. Mean values of total titratable acidity, anthocyanins and flavonoids in the myrtle powder in laminated package during storage at different temperatures

\begin{tabular}{|c|c|c|c|c|c|c|}
\hline \multirow{2}{*}{$\begin{array}{l}\text { Time } \\
\text { (days) }\end{array}$} & \multicolumn{2}{|c|}{$\begin{array}{l}\text { Total titratable acidity } \\
\text { (\% citric acid })\end{array}$} & \multicolumn{2}{|c|}{$\begin{array}{l}\text { Anthocyanins } \\
\text { (mg/100 g) }\end{array}$} & \multicolumn{2}{|c|}{$\begin{array}{l}\text { Flavonoids } \\
(\mathrm{mg} / \mathbf{1 0 0} \mathrm{g})\end{array}$} \\
\hline & $30{ }^{\circ} \mathrm{C}$ & $40{ }^{\circ} \mathrm{C}$ & $30{ }^{\circ} \mathrm{C}$ & $40{ }^{\circ} \mathrm{C}$ & $30{ }^{\circ} \mathrm{C}$ & $40^{\circ} \mathrm{C}$ \\
\hline 0 & $0.39 \mathrm{aA}$ & $0.39 \mathrm{Aa}$ & $134.50 \mathrm{aA}$ & $135.13 \mathrm{aA}$ & $101.63 \mathrm{aA}$ & $101.62 \mathrm{aA}$ \\
\hline 15 & $0.39 \mathrm{aA}$ & $0.39 \mathrm{aA}$ & $108.60 \mathrm{bA}$ & $94.86 \mathrm{bB}$ & $92.09 \mathrm{bA}$ & $87.50 \mathrm{bB}$ \\
\hline 30 & $0.40 \mathrm{aA}$ & $0.39 \mathrm{aA}$ & $88.50 \mathrm{cA}$ & $85.33 \mathrm{cB}$ & $86.92 \mathrm{cA}$ & $80.67 \mathrm{cB}$ \\
\hline 45 & $0.39 \mathrm{aA}$ & $0.38 \mathrm{aA}$ & $78.46 \mathrm{dA}$ & $76.03 \mathrm{dA}$ & $77.24 \mathrm{dA}$ & $71.11 \mathrm{~dB}$ \\
\hline 60 & $0.39 \mathrm{aA}$ & $0.39 \mathrm{aA}$ & $59.30 \mathrm{eA}$ & $49.46 \mathrm{eB}$ & $50.64 \mathrm{eA}$ & $46.94 \mathrm{eB}$ \\
\hline
\end{tabular}

Means followed by the same lowercase letter in the columns and upper case letters in the rows do not differ statistically by the Tukey test at $5 \%$ probability. 
The values of anthocyanins and flavonoids (Table 3) showed a behavior of degradation along the storage time and increase of temperature. Similar behavior was reported by Gallo et al. (2015), who stored grape juice powder at $25^{\circ} \mathrm{C}$ in LDPE packages, under the incidence of light (3500 lux) for a period of 90 days, and observed high degradation of anthocyanins during the first 15 days of storage, and by Moura (2010), who also found reduction of anthocyanins along the storage period, for organic green acerola powder stored for 360 days at temperature of $20^{\circ} \mathrm{C}$. Anthocyanins are unstable pigments, which can be degraded under the action of oxygen, temperature and $\mathrm{pH}$, or even destroyed during food storage (Oliveira et al., 2013b). Since these pigments are influenced by temperature, it justifies that the temperature of $40{ }^{\circ} \mathrm{C}$ has affected this component more significantly. Costa et al. (2013) observed small oscillations in the results of flavonoids along the storage for guarana powder.

Table 4 shows the mean values of lightness $\left(\mathrm{L}^{*}\right)$, redness $\left(+\mathrm{a}^{*}\right)$, yellowness $\left(+\mathrm{b}^{*}\right)$, chroma $\left(\mathrm{C}^{*}\right)$ and hue angle $\left(\mathrm{h}^{\circ}\right)$ obtained during the storage of myrtle powder.

Table 4. Mean values of lightness $\left(\mathrm{L}^{*}\right)$, redness $\left(+\mathrm{a}^{*}\right)$, yellowness $\left(+\mathrm{b}^{*}\right)$, chroma $\left(\mathrm{C}^{*}\right)$ and hue angle $\left(\mathrm{h}^{\circ}\right)$ of myrtle powder, in the laminated package, during storage at different temperatures

\begin{tabular}{|c|c|c|c|c|c|c|}
\hline \multirow{2}{*}{$\begin{array}{c}\text { Time } \\
\text { (days) }\end{array}$} & \multicolumn{2}{|c|}{ Lightness } & \multicolumn{2}{|c|}{ Redness } & \multicolumn{2}{|c|}{ Yellowness } \\
\hline & $30^{\circ} \mathrm{C}$ & $40^{\circ} \mathrm{C}$ & $30^{\circ} \mathrm{C}$ & $40^{\circ} \mathrm{C}$ & $30{ }^{\circ} \mathrm{C}$ & $40^{\circ} \mathrm{C}$ \\
\hline 0 & $17.15 \mathrm{aA}$ & $17.42 \mathrm{aA}$ & $17.42 \mathrm{aA}$ & $17.42 \mathrm{aA}$ & $5.87 \mathrm{aA}$ & $5.87 \mathrm{aA}$ \\
\hline 15 & $15.34 \mathrm{bA}$ & $17.21 \mathrm{aA}$ & $17.21 \mathrm{aA}$ & $15.74 \mathrm{bB}$ & $5.81 \mathrm{abA}$ & $5.39 \mathrm{bB}$ \\
\hline 30 & $14.68 \mathrm{cA}$ & $17.20 \mathrm{aA}$ & $17.20 \mathrm{aA}$ & $14.83 \mathrm{cB}$ & $5.59 \mathrm{abcA}$ & $5.16 \mathrm{bcB}$ \\
\hline 45 & $14.03 \mathrm{dA}$ & $17.15 \mathrm{aA}$ & $17.15 \mathrm{aA}$ & $14.76 \mathrm{cB}$ & $5.40 \mathrm{bcA}$ & $4.85 \mathrm{cB}$ \\
\hline 60 & $12.98 \mathrm{eA}$ & $16.95 \mathrm{aA}$ & $16.95 \mathrm{aA}$ & $14.03 \mathrm{~dB}$ & $5.29 \mathrm{cA}$ & $4.27 \mathrm{~dB}$ \\
\hline \multirow{2}{*}{$\begin{array}{c}\text { Time } \\
\text { (days) }\end{array}$} & \multicolumn{2}{|c|}{ Chroma (C*) } & \multicolumn{2}{|c|}{ Hue angle $\left(h^{0}\right)$} & \multicolumn{2}{|c|}{ Total color difference $\left(\Delta \mathbf{E}^{*}\right)$} \\
\hline & $30{ }^{\circ} \mathrm{C}$ & $40^{\circ} \mathrm{C}$ & $30{ }^{\circ} \mathrm{C}$ & $40{ }^{\circ} \mathrm{C}$ & $30{ }^{\circ} \mathrm{C}$ & $40^{\circ} \mathrm{C}$ \\
\hline 0 & $18.38 \mathrm{aA}$ & $18.38 \mathrm{aA}$ & $20.68 \mathrm{bA}$ & $20.69 \mathrm{aA}$ & - & - \\
\hline 15 & $18.02 \mathrm{aA}$ & $16.64 \mathrm{bB}$ & $18.38 \mathrm{cB}$ & $21.00 \mathrm{aA}$ & $1.82 \mathrm{bB}$ & $5.10 \mathrm{aA}$ \\
\hline 30 & $18.09 \mathrm{aA}$ & $15.64 \mathrm{cB}$ & $19.97 \mathrm{bB}$ & $21.35 \mathrm{aA}$ & $2.49 \mathrm{bB}$ & $5.68 \mathrm{aA}$ \\
\hline 45 & $18.23 \mathrm{aA}$ & $15.60 \mathrm{cB}$ & $20.78 \mathrm{bA}$ & $20.10 \mathrm{abA}$ & $3.16 \mathrm{bB}$ & $6.150 \mathrm{aA}$ \\
\hline 60 & $17.75 \mathrm{aA}$ & $14.67 \mathrm{~dB}$ & $22.20 \mathrm{aA}$ & $18.83 \mathrm{bB}$ & $4.23 \mathrm{aB}$ & $6.88 \mathrm{aA}$ \\
\hline
\end{tabular}

Means followed by the same lowercase letter in the columns and upper case letters in the rows do not differ statistically by the Tukey test at $5 \%$ probability.

The powders became darker along storage (Table 4), being evidenced by the reduction in lightness. Such darkening may have been caused by oxidation reactions, which result in the degradation of pigments. Santos et al. (2015) also reported that lightness tended to decrease from 40 days of storage in the flexible metalized packages for most treatments of co-crystallized gumbo juice. 
Regarding the effect of temperature, values of lightness, redness, yellowness and chroma decreased as temperature increased. Moura et al. (2007) stored dehydrated apple, dried at 70 ${ }^{\circ} \mathrm{C}$ for $6 \mathrm{~h}$, at three temperatures $\left(5,25\right.$ and $\left.35^{\circ} \mathrm{C}\right)$, and found that the product became darker, i.e., reduction in $\mathrm{L}^{*}$, which was higher when temperature increased.

Redness and chroma exhibited stability along the storage time at temperature of $30{ }^{\circ} \mathrm{C}$, and opposite behavior occurred at temperature of $40{ }^{\circ} \mathrm{C}$. Yellowness also decreased significantly with the storage time, demonstrating the degradation of pigments. Barbosa (2010), evaluating the chromaticity of mixed fruits (yellow mombin, mango and papaya) juice powder as a function of storage time (60 days), observed reduction in the values. Chromaticity indicates the intensity of color or saturation, and the higher its value the more intense the hue, i.e., reduction of $\mathrm{C}^{*}$ values leads to lighter-colored powders. The reduction of $+b^{*}$ may be related to the presence of heat-sensitive reactions and, depending on storage temperature and presence of light, may result in a powder with lower yellowness. Costa et al. (2013) found that the coordinate $+\mathrm{a}^{*}$ did not change along storage for passion fruit powder. The stable behavior of myrtle powder for redness and chromaticity indicates that the temperature of 30 ${ }^{\circ} \mathrm{C}$ did not influence the hue of the powders.

Hue angle showed an inverse behavior in relation to the temperatures; at $30{ }^{\circ} \mathrm{C}$, it tended to increase along the storage and, at $40{ }^{\circ} \mathrm{C}$, it showed stability until 45 days and a significant reduction at 60 days. There was not a well-defined behavior of $\left(\mathrm{h}^{\circ}\right)$ with the increment in temperature. Barbosa (2010) evaluated hue angle $\left(h^{\circ}\right)$ in mixed fruit juice powder along the storage time (60 days) and observed reduction in the values at the time of 40 days, which remained stable until 60 days. Moura (2010) observed the same hue for organic green acerola powder stored for 360 days at $20^{\circ} \mathrm{C}$, claiming that this behavior may occur because the product has little pigmentation and, therefore, it is not possible to observe an alteration in the hue along the storage.

The total color difference $\left(\Delta \mathrm{E}^{*}\right)$ at temperature of $30^{\circ} \mathrm{C}$ remained stable until 45 days and, at 60 days, its value was lower than 5 . At $40^{\circ} \mathrm{C}$, it remained stable until 60 days but, from 15 days of storage on, the samples already showed value higher than 5. Powders with low values of $\Delta \mathrm{E}^{*}$ are considered ideal, because low values of total color difference are highly desirable, indicating that the pigment maintained the color closest to the original one (Silva et al., 2013). If $\Delta \mathrm{E}^{*}$ exhibits values from 0 to 1.5 , the sample is considered virtually identical to the original one, by visual observation. When $\Delta \mathrm{E}^{*}$ is within the interval from 1.5 to 5 , the difference between colors is already noticeable and, for values higher than 5 , the difference is evident (Obón et al., 2009). Gallo et al. (2015), evaluating the stability of grape juice powder stored in vacuum-sealed LDPE packages at $25^{\circ} \mathrm{C}$ under incidence of light (3500 lux), found $\Delta \mathrm{E}^{*}<1.5$ until the 7 th day of storage and $1.5<\Delta \mathrm{E}^{*}<5$ from 15 th to 90 th day of storage, in the formulation of maltodextrin with soybean protein isolate (SPI 1), indicating good stability of the material in the maintenance of the product's color.

\subsection{Degradation Kinetics}

Table 5 shows the kinetics of degradation of lyophilized myrtle powder, during 15 days at different temperatures. 
Table 5. Kinetic parameters for the degradation of anthocyanins and flavonoids in myrtle powder, stored at different temperatures

\section{Anthocyanins}

Flavonoids

\begin{tabular}{|c|c|c|c|c|c|c|c|}
\hline \multirow[b]{2}{*}{ Model } & \multirow[b]{2}{*}{ Temp. $\left({ }^{\circ} \mathrm{C}\right)$} & \\
\hline & & $\begin{array}{c}k \\
\left(\text { day }^{-1}\right)\end{array}$ & $\mathbf{R}^{2}$ & $\begin{array}{c}\theta_{1 / 2} \\
\text { (day) }\end{array}$ & $\begin{array}{c}k \\
\left(\text { day }^{-1}\right)\end{array}$ & $\mathbf{R}^{2}$ & $\begin{array}{l}\theta_{1 / 2} \\
\text { (day) }\end{array}$ \\
\hline \multirow{3}{*}{ Zero-order } & 20 & 6.8062 & 0.9707 & 10.26 & 5.4515 & 0.9482 & 11.51 \\
\hline & 30 & 6.1913 & 0.9470 & 9.46 & 6.2805 & 0.9806 & 9.72 \\
\hline & 40 & 5.5445 & 0.7273 & 7.93 & 5.5166 & 0.9141 & 9.26 \\
\hline \multirow{4}{*}{ First-order } & Temp. $\left({ }^{\circ} \mathrm{C}\right)$ & $\begin{array}{c}k \\
\left(\text { day }^{-1}\right)\end{array}$ & $\mathbf{R}^{2}$ & $\begin{array}{l}\theta_{1 / 2} \\
\text { (day) }\end{array}$ & $\begin{array}{c}k \\
\left(\text { day }^{-1}\right)\end{array}$ & $\mathbf{R}^{2}$ & $\begin{array}{c}\theta_{1 / 2} \\
\text { (day) }\end{array}$ \\
\hline & 20 & 0.0762 & 0.8209 & 9.09 & 0.0560 & 0.8405 & 12.37 \\
\hline & 30 & 0.1042 & 0.9083 & 6.65 & 0.0753 & 0.9160 & 9.20 \\
\hline & 40 & 0.1626 & 0.6829 & 4.26 & 0.0971 & 0.9450 & 7.13 \\
\hline \multirow{4}{*}{ Second-order } & Temp. $\left({ }^{\circ} \mathrm{C}\right)$ & $\begin{array}{c}k \\
\left(\text { day }^{-1}\right)\end{array}$ & $\mathbf{R}^{2}$ & $\begin{array}{c}\theta_{1 / 2} \\
\text { (day) }\end{array}$ & $\begin{array}{c}k \\
\left(\text { day }^{-1}\right)\end{array}$ & $\mathbf{R}^{2}$ & $\begin{array}{c}\theta_{1 / 2} \\
\text { (day) }\end{array}$ \\
\hline & 20 & 0.0014 & 0.7222 & 2.68 & 0.0009 & 0.8073 & 6.64 \\
\hline & 30 & 0.0019 & 0.7825 & 2.27 & 0.0013 & 0.8961 & 4.23 \\
\hline & 40 & 0.0035 & 0.8439 & 1.76 & 0.0015 & 0.9350 & 4.69 \\
\hline
\end{tabular}

The experimental data of anthocyanins and flavonoids obtained in the degradation kinetics fitted well to zero-, first- and second-order kinetic models. In general, the best fits for anthocyanins and flavonoids occurred with the zero-order model, showing the highest $\mathrm{R}^{2}$. This type of kinetic behavior mainly occurs when there are limitations in the diffusion of certain components of the reaction, and the enzymatic browning reaction of dehydrated products is an example (Moura et al., 2007).

The reaction speed constant $(k)$ is an indicator that allows us to predict the thermal degradation of anthocyanins, and the lower the value of $k$, the better the stability of 
anthocyanins (Loypimai et al., 2016). In first- and second-order models, the higher the temperature, the higher the value of $k$, indicating that reaction speed increases with the increment in temperature; inverse and atypical behavior was observed in the zero-order model for anthocyanins and flavonoids. The values of $k$ for anthocyanins increased with temperature $\left(4-45^{\circ} \mathrm{C}\right.$ ) in extracts of Hibiscus (Hibiscus sabdariffa L.) (Cisse et al., 2012), and in beverages of Andean blackberry, açaí and black carrot extracts, stored at temperatures of 20, 30 and $50{ }^{\circ} \mathrm{C}$ (Zozio et al., 2011). The differences in $k$ values may be related to the physicochemical composition of the product in which the anthocyanins are present, influenced by, for instance, phenolic compounds, ions and pH (Sinela et al., 2017).

Anthocyanin degradation is mainly caused by oxidation, cleavage of the covalent bond or advanced oxidation reactions due to the thermal processing (Patras et al., 2010).

Different studies report that anthocyanin degradation at temperatures of up to $100{ }^{\circ} \mathrm{C}$ during food processing or storage follows a first-order kinetic model: strawberry syrup (Skrede et al., 1992), black rice (Hou et al., 2013), purple-fleshed sweet potato (Li et al., 2013), concentrated juice of black carrot (Türkyilmaz and Özkan, 2012), with coefficients of determination ranging from 0.68 to 0.91 .

Temperature can also directly influence the half-life time of anthocyanins and flavonoids in the myrtle powder, being decreased as temperature increased, and the highest values were found at the temperature of $20^{\circ} \mathrm{C}$, at 10.26 and 11.51 days, respectively.

The Arrhenius equation parameters and Q10 factor values for anthocyanins and flavonoids of myrtle powder are presented in Table 6. The values obtained for myrtle powders of the activation energy necessary to change anthocyanins and flavonoids indicate that anthocyanins are more dependent on temperature than flavonoids, tending to be significantly more sensitive to an increase of temperature compared with flavonoids. The studied parameters exhibited values below the range reported by Lund (1979). According to this author, for alterations of color, texture and taste of food products, $E_{a}$ values should be within the range of 41-125 kJ mol'-1.

Kirca et al. (2007) found $E_{a}$ of 68.8-95.1 kJ.mol ${ }^{-1}$ for the degradation of total anthocyanins in the concentrated juice of black carrot ( 30 and $64^{\circ} \mathrm{Brix}$ ) (Daucus carota ssp. sativus). Cisse et al. (2012) reported the changes of $\mathrm{E}_{\mathrm{A}}$ from 22 to $26 \mathrm{~kJ}^{\mathrm{mol}}{ }^{-1}$ for degradation of the anthocyanin in the aqueous extracts from Roselle calyx (Hibiscus sabdariffa var. Thai) stored for 6 months at temperatures of $4-45^{\circ} \mathrm{C}$. 
Table 6. Arrhenius equation parameters and Q10 factor for anthocyanins and flavonoids of myrtle powder stored

\begin{tabular}{|c|c|c|c|c|c|c|}
\hline \multirow{2}{*}{ Parameters } & \multirow{2}{*}{$\begin{array}{c}\text { Interval } \\
\left({ }^{\circ} \mathrm{C}\right)\end{array}$} & \multicolumn{3}{|c|}{ Arrhenius parameters } & \multicolumn{2}{|c|}{ Temperature coefficient $\left(Q_{10}\right)$} \\
\hline & & $\operatorname{Ln} A$ & $\mathbf{E}_{\mathrm{a}}\left(\mathbf{k J} \cdot \mathrm{mol}^{-1}\right)$ & $\mathbf{R}^{2}$ & $\left(20-30{ }^{\circ} \mathrm{C}\right)$ & $\left(30-40^{\circ} \mathrm{C}\right)$ \\
\hline Anthocyanins & $20-40$ & 0.2766 & 7.8147 & 0.9920 & 0.91 & 0.89 \\
\hline Flavonoids & $20-40$ & 7.1851 & 0.5666 & 0.9821 & 1.15 & 0.88 \\
\hline
\end{tabular}

\section{Conclusions}

Along the storage of myrtle powder at both temperatures $\left(30\right.$ and $40{ }^{\circ} \mathrm{C}$ ), there were reductions in the contents of anthocyanins, flavonoids and lightness, whereas acidity remained stable the moisture content and water activity were increased.

Powders maintained at $40{ }^{\circ} \mathrm{C}$ were more sensitive to the alterations of anthocyanins, flavonoids, lightness, yellowness and redness, negatively affecting the visual attributes.

For anthocyanin and flavonoid degradation kinetics, the zero-order was the best model to represent the behaviors together with higher stability at the temperature of $20^{\circ} \mathrm{C}$.

\section{References}

Arlindo, M., Queiroz, A. J. M., \& Figueiredo R. M. F. (2007). Armazenamento de pimentão em pó em embalagem de polietileno. Revista Brasileira de Produtos Agroindustriais, 9(2), 111-118. https://doi.org/10.15871/1517-8595/rbpa.v9n2p111-118

Barbosa, S. J. (2010). Qualidade de suco em pó de mistura de frutas obtido por spray drying (Dissertação de Mestrado). Universidade Estadual de Montes Claros - Unimontes.

Cecchi, H. M. (2003). Fundamentos teóricos e práticos em análise de alimentos (2. ed.). São Paulo: Editora Unicamp. https://doi.org/10.7476/9788526814721

Cisse, M., Vaillant, F., Kane, A., Ndiayea, O., \& Dornier, M. (2012). Impact of the extraction procedure on the kinetics of anthocyanin and colour degradation of roselle extracts during storage. Journal of the Science of Food and Agriculture, 92(6), 1214-1221. https://doi.org/10.1002/jsfa.4685

Costa, J. N. D. A., Figueiredo, R. W. D. E., Sousa, P. H. M. D. E., Gonzaga, M. L. D. A., Constant, P. B. L., \& Soares, D. J. (2013). Study of the stability of passion fruit (Passiflora edullis $f$. flavicarpa) powder from organic farming. Semina: Ciências Agrárias, 34(2), 705-716. https://doi.org/10.5433/1679-0359

Ferrari, C. C., Germer, S. P. M., Alvim, I. D., Vissotto, F. Z., \& Aguirre, J. M. (2012). Influence of carrier agents on the physicochemical properties of blackberry powder produced by spray drying. International Journal of Food Science \& Technology, 47(6), 1237-1245. 
https://doi.org/10.1111/j.1365-2621.2012.02964.X

Francis, F. J. (1982). Analysis of anthocyanins. In: MARKAKIS, P. Anthocyanins as food colors. New York: Academic Press. p. 181-207. https://doi.org/10.1016/B978-0-12-472550-8.50011-1

Galdino, P. O., Figueirêdo, R. M. F., Queiroz, A. J. M., Galdino, P. O., \& Fernandes, T. K. S. (2016). Stability of cactus-pear powder during storage. Revista Brasileira de Engenharia Agrícola e Ambiental, 20, 169-173.

https://doi.org/10.1590/1807-1929/agriambi.v20n2p169-173

Gallo, T. C. B., Moser, P., \& Telis, V. R. N. (2015). Estabilidade de suco de uva em pó microencapsulado por atomização. In XXXVII Congresso Brasileiro de Sistemas Particulados, Universidade Federal de São Carlos, São Paulo. https://doi.org/10.5151/ENEMP2015-TC-531

Han, N. S., Ahmad, W. A. N. W., \& Ishak, W. R. (2016). Quality Characteristics of Pleurotus sajor-caju powder: Study on nutritional compositions, functional properties and storage stability. Sains Malays, 45(11), 1617-1623.

Hou, Z., Qin, P., Zhang, Y., Cui, S., \& Ren, G. (2013). Identification of anthocyanins isolated from black rice (Oryza sativa L.) and their degradation kinetics. Food Research International, 50(2), 691-697. https://doi.org/10.1016/j.foodres.2011.07.037

Jangam, S. V., Joshi, V. S., Mujumdar, A. S., \& Thorat, B. N. (2008). Studies on dehydration of sapota (Achras zapota). Journal Drying Technology, 26(3), 369-377. https://doi.org/10.1080/07373930801898190

Kirca, A., Özkan, M., \& Cemeroglu, B. (2007). Effects of temperature, solid content and pH on the stability of black carrot anthocyanins. Food Chemistry, 101(1), 212-218. https://doi.org/10.1016/j.foodchem.2006.01.019

Li, X., Zheng, Z., Liu, M., Zhu, S., Wang, M., \& Qu, L. (2013). Identification and thermal stability of purple-fleshed sweet potato anthocyanins in aqueous solutions with various $\mathrm{pH}$ values and fruit juices. Food Chemistry, 136, 1429-1434. https://doi.org/10.1016/j.foodchem.2012.09.054

Loypimai, P., Moongngarm, A., \& Chottanom, P. (2015). Thermal and pH degradation kinetics of anthocyanins in natural food colorant prepared from black rice bran. Journal of Food Science and Technology, 53(1), 461-470. https://doi.org/10.1007/s13197-015-2002-1

Mishra, P., Mishra, S., \& Mahanta, C. (2014). Effect of maltodextrin concentration and inlet temperature during spray drying on physicochemical and antioxidant properties of amla (Emblica officinalis) juice powder. Food and Bioproducts Processing, 92(3), 252-258. https://doi.org/10.1016/j.fbp.2013.08.003

Moura, S. C. S. R., Berbari, S. A., Germer, S. P. M., Almeida, M. E. M., \& Fefim, D. A. (2007). Determinação da vida-de-prateleira de maçã-passa por testes acelerados. Ciência e Tecnologia de Alimentos, 27(1), 141-148. https://doi.org/10.1590/S0101-20612007000100025 
Obón, J. M., Castellar, M. R., Alacid, M., \& Fernández-López, J. A. (2009). Production of a red-purple food colorant from Opuntia stricta fruits by spray drying and its application in food model systems. Journal of Food Engineering, 90(4), 471-479. https://doi.org/10.1590/S0101-20612007000100025

Oliveira, A. N., Ramos, A. M., Chaves, J. B. P., \& Valente, M. E. R. (2013a). Cinética de degradação e vida-de-prateleira de suco integral de manga. Ciência Rural, 43(1), 172-177. https://doi.org/10.1590/S0103-84782012005000147

Oliveira, A. S., Figueirêdo, R. M. F., Queiroz, A. J. M., \& Brito, J. G. (2015). Estabilidade da polpa do Cereus jamacaru em pó durante o armazenamento. Revista Brasileira de Engenharia $\begin{array}{llll}\text { Agrícola Ambiental, } & \text { 19(2), }\end{array}$ https://doi.org/10.1590/1807-1929/agriambi.v19n2p147-153

Oliveira, M. I. S., Tonon, R. V., Nogueira, R. I., \& Cabral, L. M. C. (2013b). Estabilidade da polpa de morango atomizada utilizando diferentes agentes carreadores. Brazilian Journal Food Technology, 16(4), 310-318. https://doi.org/10.1590/S1981-67232013005000037

Patras, A., Brunton, N. P., O’Donnell, C., \& Tiwarib, B. K. (2010). Effect of thermal processing on anthocyanin stability in foods; mechanisms and kinetics of degradation. Trends in Food Science \& Technology, 21(1), 3-11. https://doi.org/10.1016/j.tifs.2009.07.004

Santos, I. P., Rocha, L. A. C., Alves, É. E., Cano-Chauca, M. N., \& Aguiar, M. C. S. (2015). Características físico-químicas e estabilidade do suco de umbu co-cristalizado com sacarose. Boletim Centro de Pesquisa de Processamento de Alimentos, 33(1), 1-17. https://doi.org/10.5380/cep.v33i1.43801

Silva, P. I., Stringheta, P. C., Teófilo, R. F., \& Oliveira, I. R. N. (2013). Parameter optimization for spray-drying microencapsulation of jaboticaba (Myrciaria jaboticaba) peel extracts using simultaneous analysis of responses. Journal of Food Engineering, 117(4), 538-544. https://doi.org/10.1016/j.jfoodeng.2012.08.039

Sinela, A., Rawat, N., Mertz, C., Achir, N., Fulcrand, H., \& Dornier, M. (2017). Anthocyanins degradation during storage of Hibiscus sabdariffa extract and evolution of its degradation products. Food Chemistry, 214(1), 234-241. https://doi.org/10.1016/j.foodchem.2016.07.071

Skrede, G., Wrolstad, R. E., Lea, P., \& Enersen, G. (1992). Color stability of strawberry and blackcurrant syrups. Journal of Food Science, 57(1), 172-177. https://doi.org/10.1111/j.1365-2621.1992.tb05449.x

Tehrany, E. A., \& Sonneveld, K. (2010). Packaging and the shelf life of milk powders. In: Food packaging and shelf life, a practical guide. CRC Press, Boca Raton, London, f.408. https://doi.org/10.1201/9781420078459-c7

Türkyilmaz, M., \& Özkan, M. (2012). Kinetics of anthocyanin degradation and polymeric colour formation in black carrot juice concentrates during storage. International Journal of Food Science \& Technology, 2273-2281. https://doi.org/10.1111/j.1365-2621.2012.03098.x 


\section{Macrothink}

Tze, N. L., Han, C. P., Yusof, Y. A., Ling, C. N. L., Talib, R. A., Taip, T. S., \& Aziz, M. G. (2012). Physiochemical and nutritional properties of spray-dried pitaya fruit powder as natural colorant. Food Science and Biotechnology, 21(3), 675-682. https://doi.org/10.1007/s10068-012-0088-z

Wong, C. W., \& Lim, W. T. (2016). Storage stability of spray-dried papaya (Carica papaya L.) powder packaged in aluminium laminated polyethylene (ALP) and polyethylene terephthalate (PET). International Food Research Journal, 23(5), 1887-1894.

Yu, H., Zheng, Y., \& Li, Y. (2015). Shelf life and storage stability of spray-dried bovine colostrum powders under different storage conditions. Journal of Food Science and Technology, 52(2), 944-951. https://doi.org/10.1007/s13197-013-1046-3

Zozio, S., Pallet, D., \& Dornier, M. (2011). Evaluation of anthocyanin stability during storage of a coloured drink made from extracts of the Andean blackberry (Rubus glaucus Benth.), açai (Euterpe oleracea Mart.) and black carrot (Daucus carota L.). Fruits, 66, 203-215. https://doi.org/10.1051/fruits/2011030

\section{Copyright Disclaimer}

Copyright for this article is retained by the author(s), with first publication rights granted to the journal.

This is an open-access article distributed under the terms and conditions of the Creative Commons Attribution license (http://creativecommons.org/licenses/by/4.0/). 